\title{
RELATIVE PRIORITY OF MARITIME LIENS
}

\author{
JoHN K. BEACH
}

This is a plea for the adoption of the broad generalization laid down in The Bold Buccleugh, that all maritime liens, from whatever source arising, are to be paid in the inverse order of their accrual. It was said in that case that "This rule which is simple and intelligible, is in our opinion applicable to all cases." Yet though The Bold Buccleugh has been approved in principle both by the House of Lords ${ }^{2}$ and by our own Supreme Court, ${ }^{3}$ the generalization logically deducible from that principle has not been formally adopted by either of those high tribunals. 'The result is that much uncertainty still exists in the decisions and the textbooks as to the underlying principle controlling priorities among maritime liens. An exception to the above generalization should probably be made in favor of liens for mariners' wages, not only for the traditional and sentimental reasons intimated in the John $G$. Stevens, ${ }^{4}$ but on the more solid ground that such liens cannot be treated as secret liens since everybody knows that mariners are not paid in advance. Local rules for arbitrarily determining what liens for supplies and repairs shall be deemed contemporaneous, and so of equal rank, are also excepted. ${ }^{5}$

It would not be easy to trace with accuracy the development of the modern law of maritime liens. The opinion of Mr. Justice Curtis in The Young Mechanic ${ }^{6}$ exhausts the subject of its relation to the Roman Law. He points out that while the express hypothecation of the ship by bottomry was recognized as creating a jus in re, the privilege or preference accorded to claims for advances to build, purchase, or equip the ship, or to provide for necessary repairs and supplies in the course of the voyage, was a mere personal privilege to be paid in preference to general creditors. If that be so, the preference was merely incidental to an equitable apportionment of the fund among attaching creditors. On the other hand, the doctrine of tacit hypothecation based on benefits conferred was well established and is apparently as applicable to the building or repair of a ship as of a house; but no doubt the weight of scholarship is in accord with the conclusion expressed by the learned justice. Reddie says that the preference was given inspection of priority in date, on the ground that such advances preserved the fund for all creditors. ${ }^{7}$

\footnotetext{
${ }^{1}$ The Bold Buccleugh (1851) 7 Moore, P. C. 267.

${ }^{2}$ Currie v. McKnight [1896] A. C. 97.

s The John G. Stevens (1898) I70 U. S. I13, 18,Sup. Ct. 544.

* Supra note 3, at p. II9.

- The forty day rule for harbor boats in New York harbor, the season of navigation rule on the Great Lakes, and the ninety day rule in the Western District of Washington.

- (1855, C. C. D. Me.) Fed. Cas. no. 18180.

"An Historical Vicw of the Law of Maritime Commerce (1841) 9r.
} 
In the dark ages following the fall of Rome commercial law practically disappears from our sight, and when the revival of sea commerce required a restatement of the maritime law, the prejudice against secret liens on movables had imbedded itself so deeply into the local law of England and of most European states that even the express hypothecation of ships by bottomry was, for a time, excluded. ${ }^{8}$ In the Rules of Oleron and the Laws of Wisly, a tacit hypothecation of the ship is recognized for money borrowed in a foreign port, which probably originated in the necessity of some device for giving the ship credit in a foreign port, rather than from any conscious adoption of the Roman doctrine of hypothecation. Such would seem to be the explanation of Reddie's statement that express hypothecations by bottomry and respondentia first reappear in the code of the Hanse Towns. ${ }^{9}$ It is not necessary to this discussion to pursue any further the development of the maritime lien on the continent.

In England the idea of jurisdiction over the ship founded upon a pre-existing maritime lien seems not to have arisen until a later date. Characteristically, it grew out of the procedure, and also out of the attempt to put the Admiralty jurisdiction beyond the reach of writs of prohibition issued by the Common Law courts. Its development is stated by Jeune, J. in The Dictator, ${ }^{10}$ in Halsbury's Laws of England, ${ }^{11}$ and by Maclachlan. ${ }^{12}$ From these it appears that the Admiralty jurisdiction was first exercised by the arrest of the defendant as a mode of compelling him to give bail for appearance and security. Then the seizure of any of the defendant's property found in tidal waters was substituted for the arrest of his person, and finally the seizure became limited to the very ship in question. $U_{p}$ to this stage of its development, the English maritime lien was merely a procedural $r \in$ medy. As to the origin of the idea that the seizure was for the purpose of enforcing a pre-existing lien which had attached to the ship at a place beyond the common law jurisdiction, Lord Halsbury says in a note, "One opinion is that the source is to be found in the ancient law of deodand, the ship being supposed to be itself responsible to the amount of the claim against it (see Holmes, Common Law pp. 25-27) but the more tenable theory would seem to be that the present law of maritime lien has sprung from the Admiralty practise of arrest to compel appearance and security."13 Of course, the courts of a country which was once a province of Rome, and in whose Black Book of the Admiralty the Rules of Oleron are inscribed, were not ignorant of the doctrine of hypothecation. As early as I7xI Lord Holt is reported as

${ }^{8}$ I Ripert, Droit Maritime (2d ed. r920) 20.

Reddie, op. cit. 255.

${ }^{10}$ [I892] P. 304, 3II.

11 Vol. I, p. 60 .

${ }^{12}$ Lawe of Merchant Shipping (5th ed. I9II) 785.

${ }^{23}$ Vol. I, p. 6r. 
saying, "By the maritime law every contract of the master implies an hypothecation; but by the common law it is not so, unless it be so expressly agreed."14 Whatever may have been the course of its development, there can be no doubt that the concept, which finally emerged, of a jus in re expressly or tacitly created by contracts of the master necessary to the completion of the voyage, was borrowed from Rome.

Referring to our own law, Mr. Justice Curtis, in "The Young Mechanic,"15 since approved by the Supreme Court, ${ }^{16}$ identified the maritime lien with Pothier's definition of hypothecation, and declared it to be "The right which a creditor has in a thing of another, which right consists in the power to cause that thing to be sold in order to have the debt paid out of the price. This is a jus in re."

Thus, until within recent years, the maritime lien of the English and American law was identified with Roman hypothec, despite the fact that at the Roman law successive hypothecations, being primarily intended solely for the security of the creditor, were for that reason normally payable in the order of their priority. But since the master's authority to hypothecate the ship, when necessary, is not chiefly for the security of the creditor, but is primarily to give credit to the ship for the further prosecution of the voyage, it is necessary to give each successive lienor a preference over all antecedent liens, of whose existence and amount the creditor can have no knowledge, and no means of information upon which he can safely rely. Before The Bold Buccleugh was decided, this necessity for giving full credit to the ship, whenever the necessity for hypothecation might arise, furnished, I think, the true and only logically adequate reason for paying contract liens in the inverse order of their priority in point of time. ${ }^{17}$

However that may be, the old theory that contract liens were to be marshalled on the basis of benefits conferred, as if maritime liens were "in the nature of rewards for services rendered,"18 prevailed and indeed still prevails. Such a theory of preference is manifestly inapplicable to claims for damage done by a ship, and so when the English Act of 1840 gave back to their admiralty courts jurisdiction $s n$ rem for damage done by ships, two new questions presented themselves, (I) whether the statute intended to impose a maritime lien on the offending ship, and, if so, (2) upon what theory were such liens

${ }^{14}$ Justin v. Bullam (I7or, K. B.) I Salk. 34.

${ }^{15}$ Supra note 6, at p. 874 .

${ }^{16}$ The J. E. Rumbell (1893) I48 U. S. I, I3 Sup. Ct. 498.

${ }^{17}$ "The vessel must get on; this is the consideration which controls every other." St. Jago de Cuba (I824, U. S.) 9 Wheat. 409. "It is essential that she should be self-reliant, - that she should be able to obtain on her own account needed repairs and supplies." Piedmont Coal Co. v. Seaboard Fisheries Co. (I920) 254 U. S. I, 9; 4 I Sup. Ct. I, 3.

${ }^{18}$ The Hope (1873, Adm.) 28 L. T. 287. 
to be ranked in priority of payment, either as between successive liens ex delicto, or with relation to contract liens. These questions came to the Privy Council for decision in The Bold Buccleugh, and Jervis, J., delivering judgment for the court, referred to The Aline, ${ }^{13}$ decided by Dr. Lushington, saying, "In that case, there was a bottomry bond before and after the collision, and the court held that the claim for damage in a proceeding in rem must be preferred to the first bondholder, but was not entitled against the second bondholder to the increased value of the vessel by reason of the repairs effected at his cost. The interest of the first bondholder taking effect from the period when his lien first attached, he was so to speak a part owner in interest at the date of the collision, and the ship in which he and others were interested was liable to its value at that date for the injury done, without reference to his claim. So by the collision the interest of the claimant attached, and dating from that event, the ship in which he was interested having been repaired was put in bottomiry by the master acting for all parties, and he would be bound by that transaction. This rule, which is simple and intelligible, is in our opinion applicable in all cases."

It is apparent that this judgment marks a distinct step in the evolution of the modern concept of a maritime lien, for it lays down for the first time, in the English law, the proposition that the right of property conferred on the lienor by the maritime lien carries with it all the risks attendant upon his part ownership in the vessel. And, if that be accepted, it must follow, as the court says, that the rule is applicable to all cases, and that his interest is subjected to every subsequent lien. The rule of preference in payment is thus put upon the secure basis of substantive law, as distinguished from remedial procedure. In Currie v. McKnight $\mathrm{t}^{20}$ Lord Watson said of The Bold Buccleugh, "The principle of that decision has been accepted in the American Courts; and in the Admiralty Courts of England it has for nearly forty years been followed in a variety of cases in which lien for damages done by a ship has been preferred to claims for salvage and seamen's wages and upon bottomry bonds." In adopting and approving the principle announced, our Supreme Court was even more specific saying, "All the interests, existing at the time of the collision, in the offending vessel, whether by way of part ownership, of mortgage, of bottomry bond, or of other maritime lien for repairs or supplies, arising out of contract with the owners or agents of the vessel, are parts of the vessel itself ${ }^{20 a}$ and as such are bound by and responsible for her wrongful acts. Any one who had furnished necessary supplies to the vessel before the collision, and had thereby acquired under our law a maritime lien or privilege in the vessel herself, was, as was said

${ }^{19}$ (r798, Adm.) I Wm. Rob. IIr.

${ }^{20}$ Supra note 2.

${ }^{20_{2}}$ Italics are those of the present writer. 
in The Bold Bucclengh, before cited, of the holder of an earlier bottomry bond under the law of England, so to speak, a part owner in interest at the date of the collision, and the ship in which he and others were interested was liable to its value at that date for the injury alone, without reference to his claim." ${ }^{21}$ True the Supreme Court was dealing in that case with the particular instance of the priority of a later lien $e x$ delicto over a lien ex contractu and, following its tradition, limited its decision to the case before it. But the principle that liens ex contractu "are parts of the vessel itself," is equally applicable to liens ex delicto, for it rests upon the nature of the interest acquired by the lienor, and not upon the transaction out of which the particular lien arose. That must be so unless there is more than one kind of a maritime lien, which is unheard of. Besides, it will be remembered that The Bold Buccleugh applied the almost self-evident proposition that a proprietary interest is subject to the ordinary risks of ownership, to three successive liens arising from bottomry, collisions and bottomry. It is submitted that The John G. Stevens authorizes, and indeed logically establishes the broad generalization laid down in The Bold Buccleugh. Such a simplification of the law governing the priority of maritime liens is much needed. The main current of authority is drifting slowly loward the doctrine of paying all maritime liens in the inverse order of their attachment, but much confusion of principle and authority still exists. This confusion results from the persistence of a complex of inadequate and more or less inconsistent theories. Some of them represent past stages in the gradual development of the concept of the lien. Thus the attempt to marshal liens according to benefits conferred corresponds roughly to the stage where the lien was treated as a procedural remedy, and the proceeds of the ship as a fund to be distributed equitably among attaching creditors. It takes two forms, one of which classifies liens in the order of their supposed inherent merit;22 the other, and more commonly accepted, gives preference to that lien which has most immediately preserved or enhanced the common security. Neither of these rules is applicable to tort liens; in fact they originated in England at a time when the admiralty jurisdiction in rem for damage done by a ship was prohibited. The first is quite inconsistent with the original purpose of the maritime lien, i. e., to give the ship credit for any emergency in a foreign port. If it were generally adopted in the maritime law, no more money could be borrowed on bottomry, which is always placed at the bottom of the list. The second works well enough as applied to contract liens, for it generally pays them in the inverse order of their attachinent, but it sometimes fails to justify its equitable pretensions, as when the entire fund is swallowed at one gulp by the latest benefactor. Other theories of priority are drawn from maxims of the civil codes.

${ }^{21}$ The John G. Stevens, supra note 3 , at p. 123.

${ }^{22} 26$ Cyc. 805-6; Hughes, Admiralty (Ig0r) 33I. 
such as "Maritime liens are adjusted by the voyage," and "The cargo is bound to the ship and the ship to the cargo;" and these have often been applied without reference to the fact that in our law they are only half true, or have been stretched beyond their proper significance. ${ }^{23}$ The uncertain rule of laches is also invoked to settle priorities between conflicting liens. As to tort liens no guiding rule at all existed until the proprietary nature of the lien vis interest was established here by The John G. Stevens; for the commonly accepted fiction that the ship itself is the wrongdoer, threw no light at all upon the rank of tort liens in the scale of priority. ${ }^{24}$

It was not to be expected that a large number of independent District Courts of co-ordinate jurisdiction shouid succeed in developing any consistent body of law out of such a mess of rules. True, conditions have improved since Judge Brown said in I88o, "it is scarcely too much to say that each court is a law unto itself"; ;5 yet in I9I5 the Circuit Court of Appeals for the Second Circuit, after struggling with the inherent merit rule, the voyage rule, the rule of laches and the forty day rule, quoted from The Panthea ${ }^{26}$ a reference "to the confusion in which the whole subject of the priority of liens is involved," and from The City of Tarvas the statement that "the subject of marshalling liens in admiralty is one which is unfortunately left in great obscurity by the authorities." 27

Such obscurity as remains is wholly unnecessary. A recognition of the proprietary nature of the interest created by maritime liens, as established in The Bold Buccleugh and The John G. Stevens sweeps away all imaginary difficulties and substitutes a rule:which is simple and intelligible and applicable to all cases. ${ }^{2 s}$

The ship mortgage act of June $5, x 920,{ }^{29}$ authorizes the creation of a new species of maritime lien by "preferred mortgages." Upon the sale of any mortgaged vessel in any suit in rem for the enforcement of a preferred mortgage the statute assigns to such lien a definite intermediate position in the scale of priority. In any case in which the lien of such a mortgage is sought to be enforced against the proceeds in competition with other maritime liens, the rule of inverse priority must be subject to the statutory exceptions.

\footnotetext{
${ }^{23}$ For recent examples see The Nissegoque (1922, E. D. N. C.) 280 Fed. 174, I92-3. The St. Paul (I921, S. D. N. Y.) 277 Fed. 99.

${ }^{24}$ Is not the tort lien a necessary corollary of the doctrine of limited liability, under which the owners may escape personal liability at will?

${ }^{25}$ The City of Tawas (I880, E. D. Mich.) 3 Fed. I70.

(I87r, Adm.) 25 L. T. 389.

${ }^{27}$ The Samuel Little (I9I5. C. C. A. 2d) 22I Fed. 308, 3I9-20.

${ }^{23}$ At least one District judge has recognized and applied the principle established by The John $G$. Stevens, but the case has apparently never been cited. The America (I909, D. N. J.) I68 Fed. 424.

20 Act of June 5, I920 (4I Stat. at L. 988); the act was held constitutional in The Oconee (1922, E. D. Va.) 280 Fed. 927; see Comments (1924) 33 Yale LAw JourNaI, 646 .
} 